\title{
Role of diffusion-weighted MR imaging in solid breast masses and complicated cysts
}

\section{Solid meme kitleleri ve komplike kistlerde diffüzyon ağırlıklı manyetik rezonans görüntülemenin yeri}

\author{
Semiha CANVERENLER ${ }^{1}$, Zehra Hilal ADIBELLI ${ }^{2}$, Emre CANVERENLER $^{3}$, Özgür Sipahi ESEN ${ }^{2}$, \\ İbrahim $\mathrm{ATASOY}^{4}$, Baha ZENGEL ${ }^{5}$
}

${ }^{1}$ Atatürk Devlet Hastanesi, Radyoloji Kliniği, Sinop

${ }^{2}$ İzmir Bozyaka Ĕ̈itim ve Araştırma Hastanesi, Radyoloji Kliniği, İzmir

${ }^{3}$ Atatürk Devlet Hastanesi, Kadın Doğum Kliniği, Sinop

${ }^{4}$ Balıklıgöl Devlet Hastanesi, Radyoloji Kliniğ̈i, Șanlıurfa

${ }^{5}$ İzmir Bozyaka Ĕ̈itim ve Araştırma Hastanesi, Genel Cerrahi Kliniği, İzmir

\begin{abstract}
Objective: The purpose of this study is to evaluate the characteristics of malign/benign lesions and complicated cysts/abscesses in diffusion weighted magnetic resonance imaging and to investigate the contribution of apparent diffusion coefficient (ADC) to differential diagnosis.

Methods: In this retrospective study; histopathologically proven 177 lesions (21 complicated cysts, 91 malign and 65 bening lesions) were evaluated in 116 women using conventional MRI and diffusion weighted imaging (DWI).

Results: Mean ADC values obtained in our study were $0.88 \pm 0.3 \times 10^{-3} \mathrm{~cm}^{2} / \mathrm{sec}$ for $91 \mathrm{malig}$ nant, and $1.52 \pm 0.3 \times 10^{-3} \mathrm{~cm}^{2} / \mathrm{sec}$ for 65 benign lesions, $0.55 \pm 0.3 \times 10^{-3} \mathrm{~cm}^{2} / \mathrm{sec}$ for $21 \mathrm{compli}-$ cated cysts/abscesses and and a statistically significant difference was detected among mean lesion $\mathrm{ADC}$ values $(\mathrm{P}<0.001)$. We calculated threshold $\mathrm{ADC}$ values to discriminate between malignant and benign lesions, and between these lesions and complicated cysts/abscesses as $1.1 \times 10^{-3} \mathrm{~cm}^{2} / \mathrm{sec}(\mathrm{P}<0.001)$, and $0.6 \times 10^{-3} \mathrm{~cm}^{2} / \mathrm{sec}(\mathrm{P}<0.001)$, respectively. The ADC values identified for complicated cysts/abscesses are significantly lower than the ADC values of benign and malign values reported in the literature.

Conclusion: As a result, the specificity, positive predictive value and negative predictive value of DWI when it is used alone are higher than conventional MRI, while sensitivity of DWI is nearly the same. DWI is effective in detecting breast lesions and also ADC value is useful in distinguishing among complicated cysts/abscesses, malignant and benign breast lesions.
\end{abstract}

Key words: Solid breast mass, complicated breast cyst, breast abscess, breast magnetic resonance imaging, diffusion-weighted imaging

\section{$\ddot{\mathbf{O Z}}$}

\begin{abstract}
Amaç: Çalışmamızın amacı, memede diffüzyon ağırlıklı manyetik resonans (MR) görüntüleme ile komplike kist-apse, benign ve malign lezyonların özelliklerinin değerlendirilmesi ve bu lezyonların açı diffüzyon katsayısının (apparent diffusion coefficient-ADC) belirlenmesidir.

Yöntem: Bu retrospektif çalışmada, 116 kadın hastaya ait histopatholojik tanısı olan 21 komplike kist, 91 malign ve 65 benign toplam 177 lezyon konvansiyonel MR ve diffüzyon ağırlıklı MR görüntüleme ile değerlendirildi.

Bulgular: Çalışmamızda, saptanan ortalama ADC değeri 91 malign lezyonda $0,88 \pm 0,3 \times 10^{-3}$ $\mathrm{cm}^{2} / \mathrm{sn}, 65$ benign lezyonda $1,52 \pm 0,3 \times 10^{-3} \mathrm{~cm}^{2} / \mathrm{sn}, 21$ komplike kiste $0,55 \pm 0,3 \times 10^{-3} \mathrm{~m}^{2} / \mathrm{sn}$ olup, ortalama ADC değerleri arasındaki fark istatistiksel olarak anlamlıdır $(\mathrm{P}<0,001)$. Malign ve benign lezyonların komplike kistlerden ayrımında eşik değer $0,6 \times 10^{-3} \mathrm{~cm}^{2} / \mathrm{sn}$ $(\mathrm{P}<0,001)$, malign ve benign lezyonların birbirinden ayrımında eşik değer $1,1 \times 10^{-3} \mathrm{~cm}^{2} / \mathrm{sn}$ $(\mathrm{P}<0,001)$ olarak tespit edilmiştir. Komplike kist ve abselerin A $\mathrm{DC}$ değerleri malign ve benign lezyonların ADC değerlerinden istatistiksel olarak anlamlı derecede düşüktür.

Sonuç: Sonuç olarak, tek başına diffüzyon MR kullanıldığında, saptanan özgülllük, pozitif ve negatif öngürü değerleri konvansiyonel MR incelemeye göre yüksek, duyarlılı ise çok yakın değerdedir. Diffüzyon MR inceleme meme lezyonlarının etkin olup, ADC değerleri lezyonların benign, malign ve komplike kist ayrımında kullanılabilir.
\end{abstract}

Anahtar kelimeler: Solid meme kitlesi, komplike meme kisti, meme apsesi, meme manyetik resonans görüntüleme, diffüzyon ağırlıklı görüntüleme
Alındığı tarih: 29.09.2016

Kabul tarihi: 11.10 .2016

Yazışma adresi: Doç. Dr. Zehra Hilal Adıbelli, 1402 Sok. 2/11, Alsancak-Konak-İzmir e-mail: adibellizehra@gmail.com 


\section{INTRODUCTION}

Despite the fact that mammography is the gold standard in screening and diagnosis of breast cancer and the diagnosis-supporting contributions of ultrasonography (USG), the desired diagnostic sensitivity and specificity of these tests have not yet been established in breast cancer. This requirement has led to new pursuits and magnetic resonance imaging (MRI) has become a radiological imaging method increasingly used in the evaluation of the breast. In conventional breast MRI evaluations, the contrast enhancement and morphological features of the lesion are used ${ }^{(1)}$. Despite high sensitivity of the conventional breast MRI in detecting breast cancer its specificity may be limited which is reportedly range between $40-80 \%$ in various studies ${ }^{(1-3)}$. There are studies reporting that adding diffusion-weighted sequences to breast MRI's increase specificity ${ }^{(4,5)}$.

Diffusion-weighted imaging (DWI) has demonstrated high accuracy rates in the characterization of breast lesions and distinguishing between malignant and benign lesions due to hypercellularity of malignant lesions ${ }^{(6)}$. The contributions of signal abnormalities identified in DWI to the diagnosis can be revealed by estimating 'apparent diffusion coefficient' (ADC). It has been reported in the literature that diffusion is restricted in DWI because of the hypercellularity of malignant breast lesions ${ }^{(7,8)}$. Also, very limited number of studies in the literature have been cited about the ADC levels of complicated cystic lesions identified by DWI . Our purpose in this study is to investigate the efficiency of diffusion-weighted breast MRI sequences in distinguishing malignant, benign solid lesions and complicated cysts/abscesses and to calculate mean ADC values.

\section{MATERIALS and METHODS}

This retrospective study was performed between November 2011 and August 2015 after obtaining the approval of the ethics committee. We retrospectively reviewed consecutive conventional breast MRI and
DWI sequences, and only histopathologically proven lesions were included in the study. Finally, 177 lesions from 116 female patients with a median age of 46 (mean, 48 \pm 12.8 ; range, 24-81) years were evaluated in this study. Ninety-one malignant, 65 benign lesions with mass and non-masslike enhancement and 21 complicated cysts/abscesses were defined as BIRADS 2-3-4-5 lesions by using conventional MRI, then sensitivity, specificity, positive diagnostic rate (positive predictive value) and negative diagnostic rate (negative predictive value) were calculated.

In our study, we performed DWI in patients who applied to our departments for breast MRI with different indications and we investigated whether the data obtained would be useful in the differential diagnosis of the lesion. The lesions defined were categorized and evaluated in three groups according to the histopathological data, as malign, benign and complicated cyst/abscess. Because complicated cysts and abscesses may restrict diffusion and are of cystic nature they were grouped separately. The mean ADCs of the malignant, benign and complicated cyst/abscess group were calculated and also ADC measurements of normal fibroglandular tissue were performed. All ADC values were analyzed statistically and also sensitivity, specificity, positive diagnostic value (positive predictive value) and negative diagnostic value (negative predictive value) were calculated again by using DWI findings. We also compared accuracy data of DWI and conventional MRI findings.

MRI examinations of the patients were performed in our radiology clinic using a $1.5 \mathrm{~T}$ MR device (Philips Achieva, Philips Medical System). Standard breast coils and $300 \mathrm{~mm}$ fields of view (FOV) were used during MRI examinations. Pre-contrast and post-contrast T1 weighted FLASH 3D (TR/TE 5.6/1.6 $\mathrm{ms}$ ) fat-suppression sequence images were obtained in the axial plane with $3 \mathrm{~mm}$-thick 32 slices. The contrast agent containing gadolinium was administered intravenously at doses of $0.1 \mathrm{mmol} / \mathrm{kg}$. In the dynamic study, after IV administration of the contrast agent, images were obtained in the axial plane at T1 weighted 3D FLASH sequences with 60 -second peri- 
ods and image acquisition was repeated at least 6 times. Images were transferred to the workstation and the time/signal curve of the dynamic contrasted images was drawn. DWI images were obtained before administration of the contrast agent using echo planar imaging (EPI) sequences at parameters TR/ $\mathrm{TE}=1741 / 74$ msec; matrix $=152 \times 122$, field of view $(\mathrm{FOV})=300 \mathrm{~m}$; slice thickness $=8.5 \mathrm{~mm}$; interslice distance $=2.1 \mathrm{~mm}$ and $\mathrm{NEX}=8$. Both breasts were evaluated in 24 slices. The fat suppression technique was used. Two different $b$ values, $b=0$ and $b=1000$ $\mathrm{mm}^{2} / \mathrm{sec}$ were used for each slice. The diffusion gradients were performed perpendicular to each other in 3 separate directions $(\mathrm{x}, \mathrm{y}, \mathrm{z})$ and isotropic (trace) DWI was obtained. Using the device console software of MRI, the ADC values were automatically measured and ADC map images were prepared from the lesions detected by using all MRI sequences especially post-contrast images. To achieve standardized conditions for analyses and to avoid contamination of the data by adjacent structures, circular regions of interest (ROI) of at least $50 \mathrm{~mm}^{2}$ were individually placed in the lesions in the same location as the ADC maps cited above, and the average ADC value was noted by each authors (S.C. and Z.H.A.) independently after four measurements and the average was taken for all lesions. In solid lesions, apparent necrotic or cystic components were avoided by referring especially to dynamic sequences of conventional MR images. ADC measurements of normal fibroglandular tissue were performed at the opposite breasts of all patients at the same level corresponding with the quadrant and/or localization of the lesion.

Both the conventional MRIs and DWIs were read in a blinded fashion by 2 radiologists with experience in breast imaging of 1 (S.C.) and 20 years (Z.H.A.), respectively. The radiologists examined each breast MR independently and made a diagnosis based on the American College of Radiology BI-RADS (Breast Imaging Reporting and Data System) lexicon. Discordant interpretations were subsequently resolved by consensus of the 2 radiologists. BIRADS 1,2, and 3 were interpreted as negative, benign, and pro- bably benign lesions, respectively. BI-RADS 4 and 5 were considered as suspect lesions and lesions highly suggestive of malignancy, respectively.

Statistical Method: In the analysis of data and the comparison of independent multiple groups with each other, the Games-Howell tests were used for One-Way Anova Post-Hoc analyses. The Cramer's V test was used to investigate the correlations between variables. The Pearson chi-Square tests were used to compare categorical data. The sensitivity, specificity, positive diagnostic value (positive predictive value) and negative diagnostic value (negative predictive value) were analyzed and expressed. The ROC (Receiver Operating Curve) analysis was performed to calculate the cut-off values. Quantitative data were expressed as mean $\pm \mathrm{SD}$ (standard deviation) and median $\pm \mathrm{IQR}$ (Inter Quartile Range) in tables. Categorical data were expressed with n numbers (n) and percentages (\%). The data was analyzed at a $95 \%$ confidence level and p-values smaller than 0.05 were regarded as statistically significant.

\section{RESULTS}

Hundred and seventy-seven lesions from 116 women were included in our study. Among these lesions, 91 malignant, 65 benign lesions with mass and non-masslike enhancement and 21 complicated cystic lesions were histopathologically evaluated. The mean age of the cases $(48 \pm 12.8 \mathrm{yrs})$, the mean

Table 1. The comparison of malign/benign/complicated cystic lesions according to age, lesion size, normal breast ADC and lesion ADC.

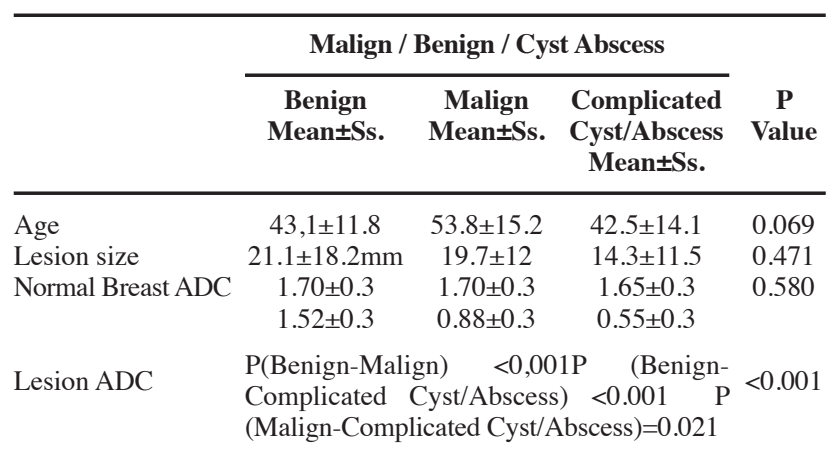

One-Way ANOVA Test-Post Hoc: Test Games-Howell Test, SD: Standard Deviation 
values for lesion size $(18.1 \pm 14.0 \mathrm{~mm})$, sizes of malignant $(19.7 \pm 12 \mathrm{~mm})$, benign lesions $(21.1 \pm 18.2$ $\mathrm{mm}$ ) and the complicated cyst/abscess group lesions $(14.3 \pm 11.5 \mathrm{~mm})$ were recorded (Table 1).

Twenty-one complicated cystic lesions underwent fine-needle aspiration biopsy (FNAB) because of MRI findings consistent with abscesses. By using conventional MRI, three of them were defined as BIRADS 4, five of them as BIRADS 2, and the others as BIRADS 3 lesions ${ }^{(9)}$.

Ninety-one malignant, 65 benign lesions with mass and non-masslike enhancement and 21 complicated cysts/abscesses were defined as BIRADS 2-34-5 lesions by using only conventional MRI findings. According to the BIRADS classification, among 177 lesions, 5 (2.82\%) BIRADS 2, 46 (26\%) BIRADS 3, $85(48.02 \%)$ BIRADS 4 and $41(23.16 \%)$ BIRADS 5 lesions were detected. Five lesions which was defined as BIRADS 2 had MRI findings consistent with abscesses and evaluated by FNAB. Among 46 lesions defined as BIRADS 3 lesions, 23 with suspicious USG and mammography findings were diagnosed by FNAB, 10 were diagnosed during histopathological examination of the material obtained from planned partial or total mastectomies performed for BIRADS 4 and 5 lesions and 13 lesions were diagnosed by histopathological examination of the specimens acquired with interventional diagnostic methods (5 FNABs, 1 tru-cut biopsy, 7 excisional biopsies) according to the patient history and physical examination and the doctor's choice. The other 126 lesions defined as BIRADS 4 and 5 were histopathologically diagnosed from specimens obtained from tru-cut biopsy, excisional biopsy and partial or total mastectomy materials.

Among 65 benign lesions biopsied, the most common benign masses were fibroadenomas $(n=22)$. The other benign lesions were proliferative breast disease $(n=11)$, phyllodes tumor $(n=4)$, breast infection $(n=7)$, intraductal papilloma $(n=3)$, fibrocystic changes $(n=4)$, radial scar $(n=2)$, lyponecrosis $(n=1)$, hamartoma $(n=1)$, benign granular cell tumor $(\mathrm{GCT})(\mathrm{n}=1)$ and 9 lesions with benign cytology. In this study, there were 91 malignant lesions (2 lobular carcinomas in situ (LCIS), 6 ductal carcinomas in situ (DCIS), 6 invasive lobular carcinomas, 76 invasive ductal carcinomas, 1 neuroendocrine breast carcinoma). According to the conventional breast MRI findings, all of 2 BIRADS 2 lesions and 43 of the BIRADS 3 lesions were diagnosed as benign, 3 as malign; 36 of the BIRADS 4 lesions as benign, 49 as malign; 39 of the BIRADS 5 lesions as malign and 2 as benign lesions. Out of the 36 lesions that were placed in the BIRADS 4 group according to MRI findings that were eventually diagnosed as benign were complicated cysts/abscesses $(n=3)$, intraductal papillomas $(n=3)$, fibroadenomas $(n=10)$, breast infections $(n=5)$, phyllodes tumors $(n=4)$, proliferative breast diseases (simple/atypical ductal hyperplasia, ductal papillary hyperplasia, apocrine metaplasia) $(n=10)$, and radial scar $(n=1)$. Three malignant lesions that we had identified as BIRADS 3 were diagnosed as DCIS $(n=2)$, and LCIS $(n=1)$ in DWI. Two BIRADS 5 lesions were diagnosed as benign (radial scar, $\mathrm{n}=1$; and benign GCT, $\mathrm{n}=1$ ). By using only conventional MRI, we achieved $96.7 \%$ sensitivity, $55.8 \%$ specificity, $69.8 \%$ positive predictive value (PPV), and 52.7\% negative predictive value (NPV).

The lesions defined were categorized and evaluated in three groups according to the histopathological dat as malignant $(n=91)$, benign $(n=65)$ lesions and complicated cysts/abscesses (21 lesions). DWI findings were evaluated in consideration of these three groups. We calculated cut-off ADC values to distinguish malignant and benign lesions from complicated cysts/abscesses $\left(0.6 \times 10^{-3} \mathrm{~cm}^{2} / \mathrm{sec}\right)$ and also malignant

Table 2. The distribution of complicated cyst/abscess, malign and benign lesions according to the lesion ADC variable.

\begin{tabular}{lcccc}
\hline & \multicolumn{3}{c}{ Malign / Benign / Cyst Abscess } & \\
\cline { 2 - 4 } $\begin{array}{l}\text { Lesion } \\
\text { ADC }\end{array}$ & $\begin{array}{c}\text { Complicated } \\
\text { Cyst/Abscess } \\
\text { n (Row \%) } \\
(\text { Column \%) }\end{array}$ & $\begin{array}{c}\text { Malign } \\
\text { n (Row \%) } \\
(\text { Column \%) }\end{array}$ & $\begin{array}{c}\text { Benign } \\
\text { n (Row \%) } \\
(\text { Column \%) }\end{array}$ & Value \\
& & & \\
\hline $0,6 \leq$ & $13(61.9 \%)(61.9 \%)$ & $8(38.1 \%)(8,8 \%)$ & $0(0 \%)(0 \%)$ & \\
$0,6-1,1$ & $8(8.5 \%)(38.1 \%)$ & $78(83 \%)(85.7 \%)$ & $8(8.5 \%)(12,3 \%)$ & $<0.001$ \\
$1,1<$ & $0(0 \%)(0 \%)$ & $5(8.1 \%)(5,5 \%)$ & $57(91.9 \%)(87,7 \%)$ & \\
\hline
\end{tabular}

Pearson Chi-Square Test-Cramer's V, $r=0.716, P<0.001$ 

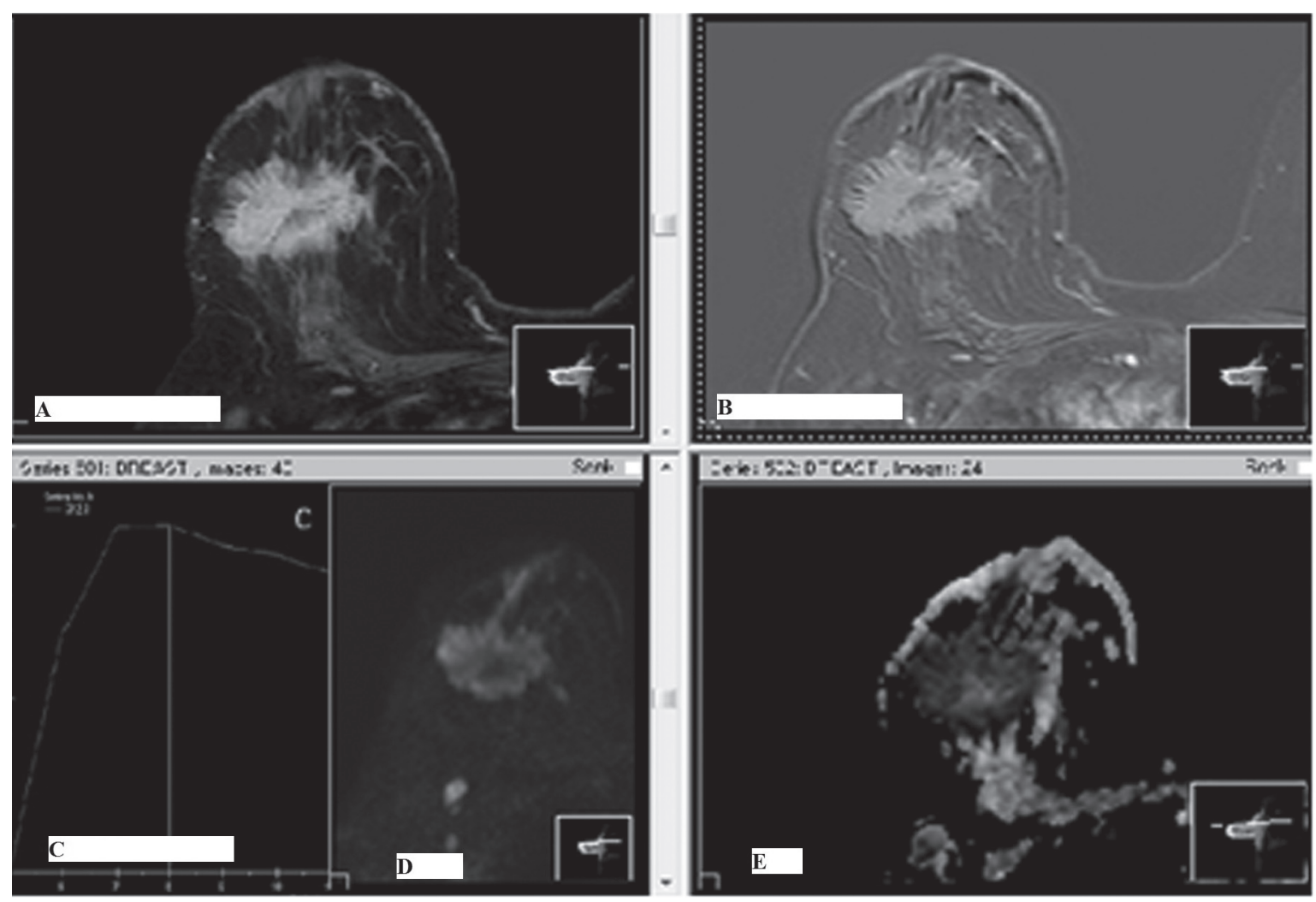

Figure 1.52 year-old female. In post-contrast (A) and dynamic (B-subtraction) images, a $5.5 \times 5 \mathrm{~cm}$ sized centrally necrotic massive lesion with spiculated borders is present the upper lateral quadrant of the right breast. The time/signal curve of the lesion is of type 3 (C). The lesion was defined as BIRADS 5 category according to these findings. In DWI, restricted diffusion can be seen in the areas other than the necrotic component of the lesion (D-b1000). The lesion ADC (E) value is $0.91 \times 10^{-3} \mathrm{~cm}^{2} / \mathrm{sec}$ and the histopathological results are consistent with invasive ductal carcinoma + cribriform type DCIS focuses.

lesions from benign lesions $\left(1.1 \times 10^{-3} \mathrm{~cm}^{2} / \mathrm{sec}\right)$ as indicated. Out of 65 benign lesions, restricted diffusion was not present in $57(87.7 \%)$ lesions and diffusion was restricted in $8(8.5 \%)$ lesions in DWI. Restricted diffusion was present in $86(94.5 \%)$ of the 91 malignant lesions and all of the $11(100 \%)$ lesions in the complicated cyst/abscess group (Table 2). The mean ADC values obtained in our study were $0.88 \pm 0.3 \times 10^{-3} \mathrm{~cm}^{2} / \mathrm{sec}$ for 91 malignant lesions (Figures 1, and 2), 1.52 $\pm 0.3 \times 10^{-3} \mathrm{~cm}^{2} / \mathrm{sec}$ for 65 benign lesions (Figure 3), $0.55 \pm 0.3 \times 10^{-3} \mathrm{~cm}^{2} / \mathrm{sec}$ for 21 complicated cysts/abscesses (Figures 4, and 5) and $1.69 \pm 0.4 \times 10^{-3} \mathrm{~cm}^{2} / \mathrm{sec}$ for the 116 normal fibroglandular tissues.

\section{DISCUSSION}

MRI is a problem-solving technique in cases where mammography and breast ultrasound are insufficient ${ }^{(10-12)}$. The contrast enhancement dynamics of the lesion reflects the vascularity of the tissue, the vascular permeability, the interstitial pressure changes and the contents of extracellular spaces. It is known that cellularity is important in detecting malignancy ${ }^{(13,14)}$. Conventional MRI does not demonstrate variations in cellularity. Additional modalities are required in these conditions. Diffusionweighted imaging differs from T1 and T2 signal features as it is the only modality that provides information about the cellularity and biological features of the tissue and thus can be used as an additional modality. Because of the high cellularity of malignant breast lesions, DWI gains importance in the characterization of the lesions. In two studies, a significant correlation was identified between the cellularity of breast lesions and ADC values ${ }^{(7,8)}$.

Two factors create microscopic mobility in biological tissues. These are molecular diffusion of water 

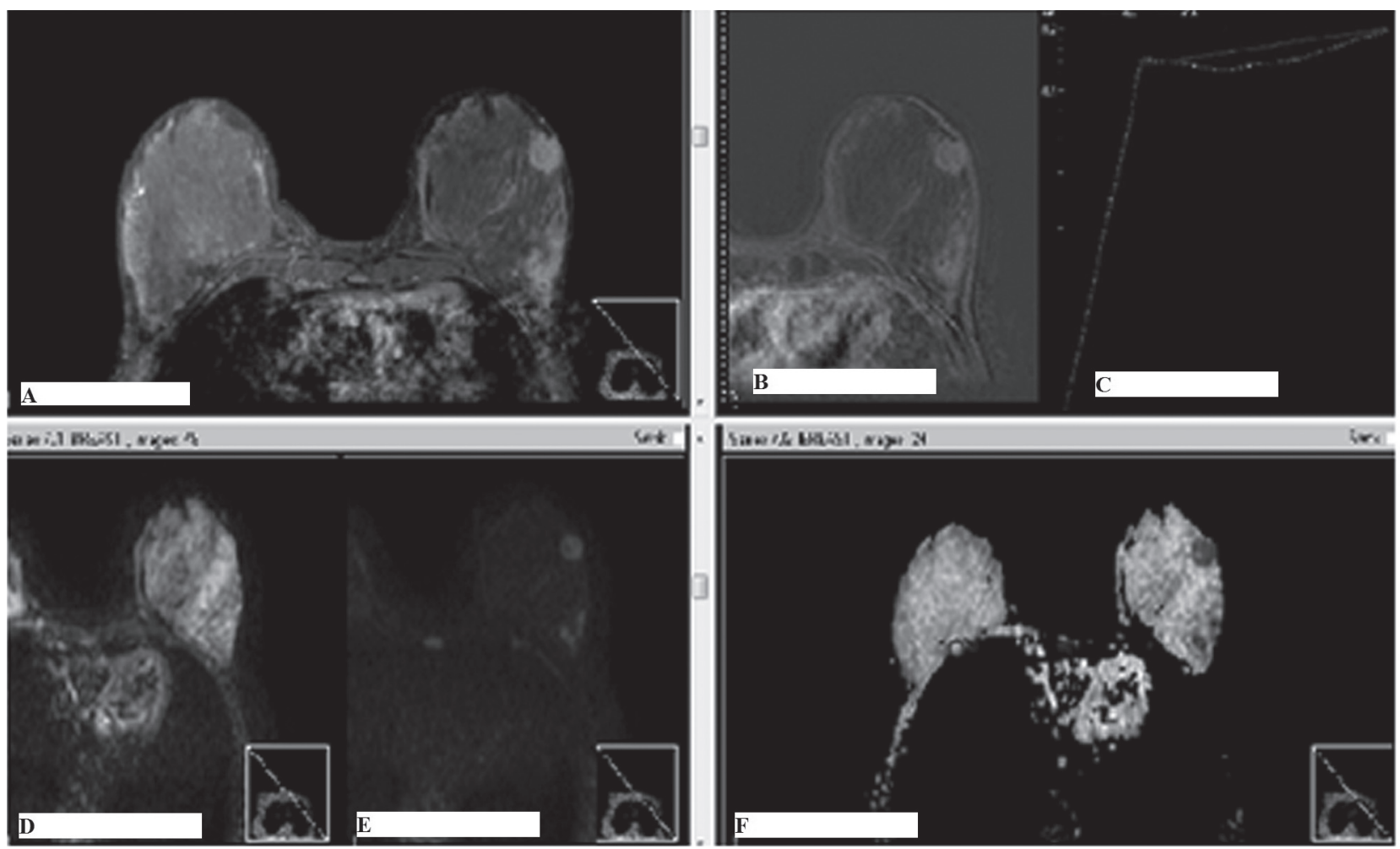

Figure 2.31-year-old female. In the left breast lower lateral quadrant a massive lesion with irregular spiculated contours leaning to the skin and a $3 \times 2 \mathrm{~cm}$ contrasted parenchymal area that is located deeper is present (A-post-contrast T1A; B-subtraction) A type 1 signal/time curve was obtained from both lesions $(C)$. The lesions were regarded as BIRADS 5 and BIRADS 4 category respectively. The lesions demonstrated restricted diffusion in DWI (D-b0; E-b1000) and the ADC (F) values were measured as $0.73 \times 10^{-3} \mathrm{~cm}^{2} / \mathrm{sec}$ and $0.74 \times 10^{-3} \mathrm{~cm}^{2} / \mathrm{sec}$ respectively. The histopathological diagnosis is consistent with invasive lobular carcinoma.

(diffusion) and capillary microcirculation (perfusion). Diffusion and perfusion affect the ADC measured in tissues. The perfusion coefficient per unit of tissue is higher than the diffusion coefficient of water ${ }^{(15)}$. Although vascular perfusion is significantly higher in malignant breast lesions ${ }^{(16)}$, to demonstrate the reduction in diffusion, high $b$ values which reduce the effect of perfusion need to be used regardless of the $\mathrm{S} / \mathrm{N}$ ratio dropping to certain levels ${ }^{(15)}$. Considering this, we used high b values of b1000 in our study to reduce the effect of perfusion.

In this study, we evaluated the manifestations of malignant, benign breast lesions and complicated cysts/abscesses in DWI and to investigate ADC values for these lesion groups. The ADC values of lesion groups and normal fibroglandular tissue derived from the literature and the ADC values we identified in our study are given in Table 3 for comparison ${ }^{(7,8,17-24)}$. As seen, although there are slight differences between the ADC values of various studies, statistically significant differences have been identified between groups in all studies. We also observed a statistically significant difference between the groups (except the difference between normal tissue and benign lesions), thus our study is consistent with literature data.

Table 3. The ADC values $\left(x_{10}^{-3} \mathrm{~cm}^{2} / \mathrm{sec}\right)$ identified in our study and similar studies.

\begin{tabular}{lcccc}
\hline & Malign & Benign & $\begin{array}{c}\text { Complicated } \\
\text { cyst/abscess }\end{array}$ & $\begin{array}{c}\text { Normal } \\
\text { breast }\end{array}$ \\
\hline Guo et al. ${ }^{(7)}$ & $0.97 \pm 0.20$ & $1.57 \pm 0.23$ & & \\
${\text { Rubesova et al. }{ }^{(17)}}^{(18)}$ & $0.95 \pm 0.027$ & $1.51 \pm 0.068$ & \\
Woodhams et al. $^{1}$ & $1.22 \pm 0.31$ & & & $2.09 \pm 0.27$ \\
Kuroki et al. $^{(19)}$ & $1.021 \pm 0.23$ & $1.448 \pm 0.45$ & \\
Hatakenaka et al. $^{(8)}$ & $1.15 \pm 0.26$ & $1.66 \pm 0.30$ & & \\
Sinha and Sinha ${ }^{(20)}$ & $1.01 \pm 0.17$ & & & \\
Marini et al. ${ }^{(21)}$ & $0.95 \pm 0.18$ & $1.48 \pm 0.37$ & \\
Luo et al. $^{(22)}$ & $0.87 \pm 0.23$ & $1.59 \pm 0.26$ & & \\
Patridge et al. ${ }^{(23)}$ & $1.25 \pm 0.27$ & $1.70 \pm 0.44$ & & \\
Arantes Pereira et. al. ${ }^{(24)}$ & $0.68 \pm 0.25$ & $1.44 \pm 0.31$ & & \\
In our study & $0.88 \pm 0.3$ & $1.52 \pm 0.3$ & $0.55 \pm 0.3$ & $1.7 \pm 0.4$ \\
& & & & \\
\hline
\end{tabular}



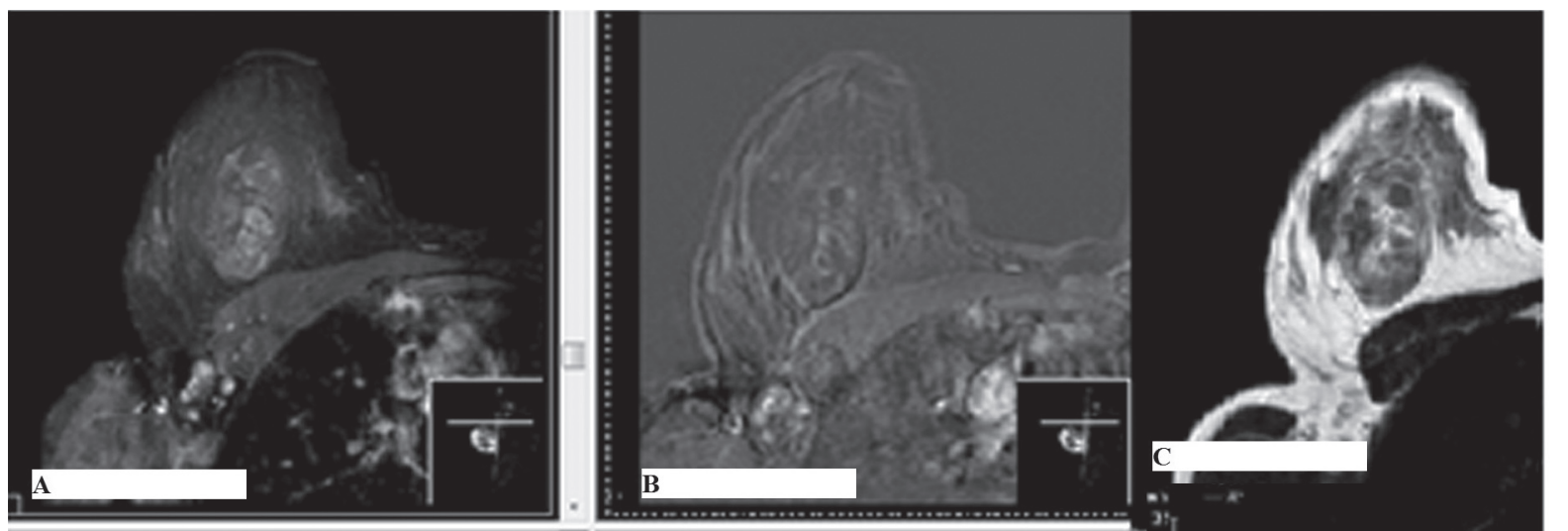

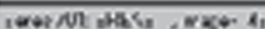
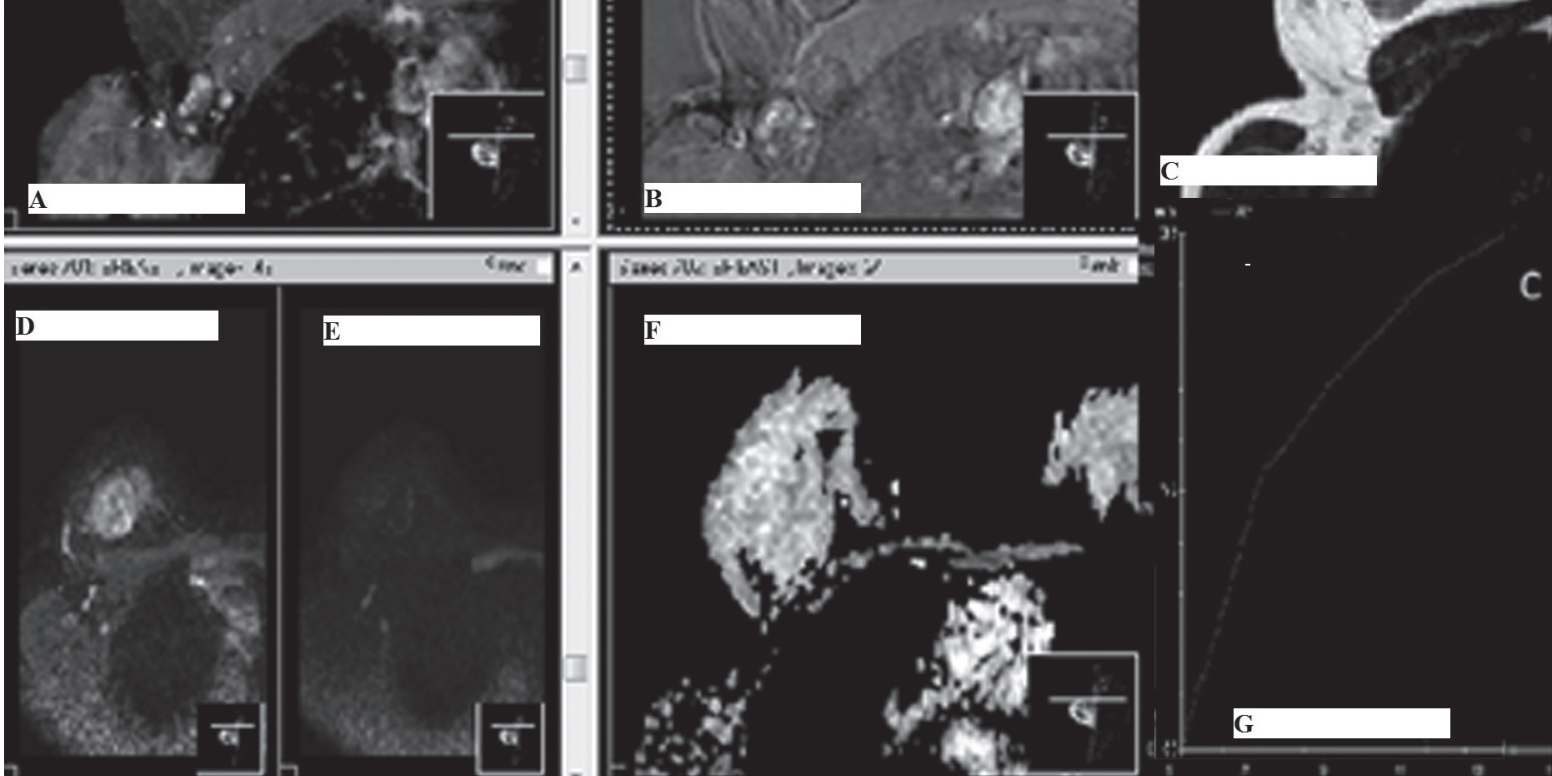

Figure 3. 43-year-old female. A $5.5 \times 4 \mathrm{~cm}$ massive lesion in the upper lateral quadrant of the right breast with sharp borders that has isohyperintense areas when compared to the parenchyma in T1 and T2 (C) sequences is present. In the post-contrast dynamic study (A-post-contrast T1, B-subtraction) mild contrast enhancement is seen and a type 1 time/signal curve (G) is present in contrast enhanced areas. The massive lesion was defined as BIRADS 4a category. The lesion does not display any restricted diffusion in DWI and the ADC (F) value was measured as $1.74 \times 10^{-3}$ $\mathrm{cm}^{2} / \mathrm{sec}$. The histopathological diagnosis is consistent with hamartoma.

The ADC values obtained in our study were $0.88 \pm 0.3 \times 10^{-3} \mathrm{~cm}^{2} / \mathrm{sec}$ for 91 malignant lesions, $1.52 \pm 0.3 \times 10^{-3} \mathrm{~cm}^{2} / \mathrm{sec}$ for 65 benign lesions, $0.55 \pm 0.3 \times 10^{-3} \mathrm{~cm}^{2} / \mathrm{sec}$ for 21 complicated cysts/abscesses and $1.69 \pm 0.4 \times 10^{-3} \mathrm{~cm}^{2} / \mathrm{sec}$ for the 116 normal fibroglandular tissues, with a statistically significant difference between mean lesion ADC values $(\mathrm{P}<0.001)$ (Table 1). When the post-hoc analyses were reviewed, it was seen that the mean ADC of the benign group lesions was significantly higher than the mean ADC of the malign group lesions ( $\mathrm{P}($ benign/ malign $<0.001$ ). The mean ADC of the malign group was statistically significantly higher than the mean ADC of the complicated cyst/abscess group $(\mathrm{P}($ malign-complicated cyst/abscess $)=0.021)$. No statistically significant difference was found when the mean ADC values of normal fibroglandular tissues of malignant, benign and complicated cyst/abscess gro- ups were compared $(\mathrm{P}<0.001)$ (Table 1).

In our study our statistically significant $(\mathrm{P}<0.001)$ ADC cut-off value for malignant/benign lesions was $1.1 \times 10^{-3} \mathrm{~cm}^{2} / \mathrm{sec}$, with $94.5 \%$ sensitivity, $87 \%$ specificity, $91 \%$, PPV, and $62.63 \%$ NPV. The specificity, PPV and NPV of DWI when it was used alone were higher than conventional MRI in our study $(55.8 \%$ specificity, $69.8 \% \mathrm{PPV}$, and $52.7 \%$ NPV of conventional MRI.), its sensitivity was comparatively lower (sensitivity 96.7\%), without any statistically significant difference between DWI, and MRI. In the literature, the specificity of DWI was found to be higher than conventional MRI, but its sensitivity decreased when it was used alone. Our study is partially consistent with literature data ${ }^{(4,5,7,8,17,18,21,22,24)}$.

Also, as seen in Table 2, our statistically significant $(\mathrm{P}<0.001)$ ADC cut-off value to distinguish malignant and benign lesions from complicated 

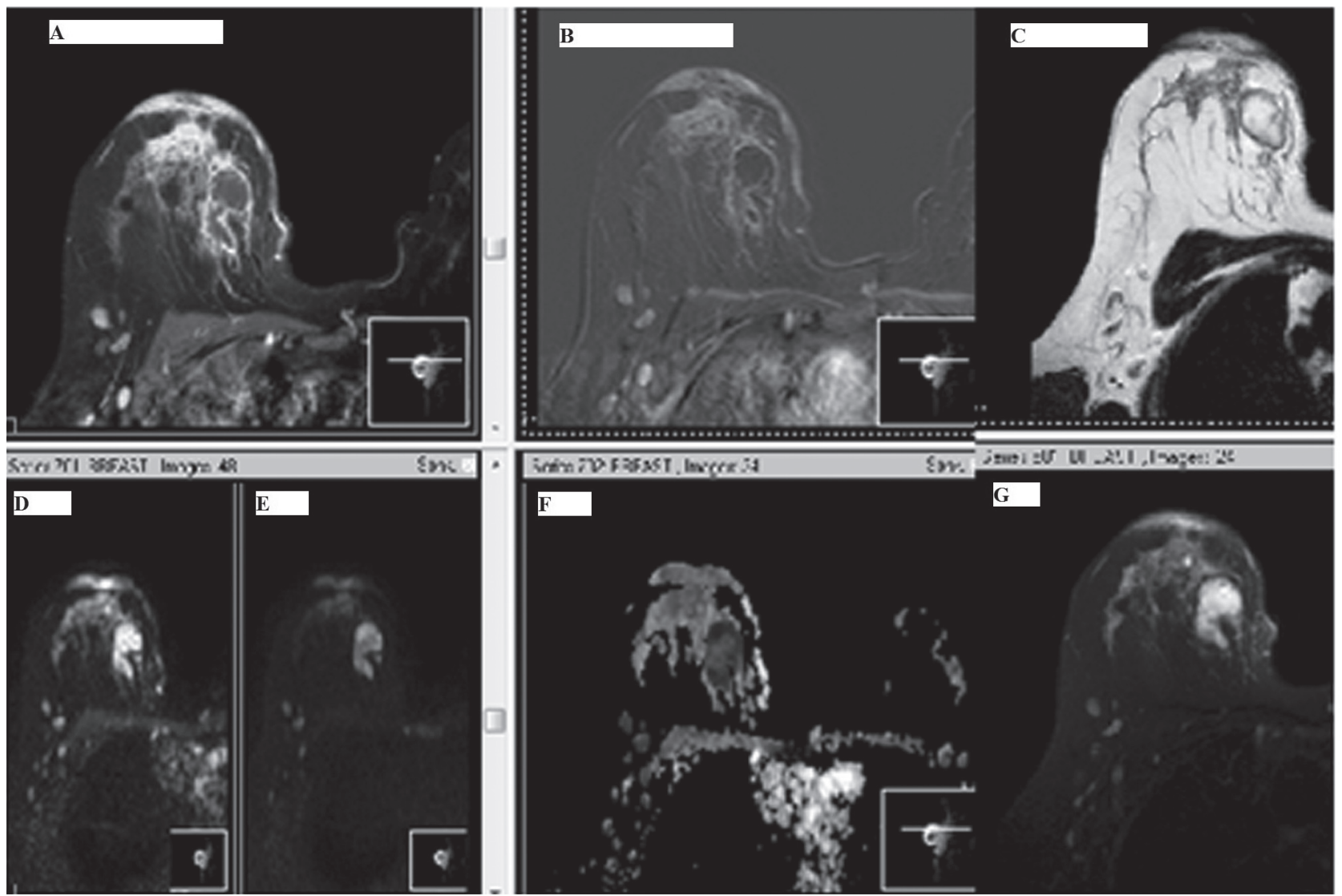

Figure 4. A 43-year-old female. A T1-T2A hyperintense (G,C) cystic lesion with a diameter of 3.3cm, circumferentially contrasting (A-post-contrast T1, B-subtraction) but with regular inner and outer borders was observed. The lesion was evaluated as BIRADS 3 category and abscess was considered in the differential diagnosis. In DWI, the lesion demonstrated restricted diffusion (D-b0; E-b1000) and the lesion ADC (F) value was measured as $0.47 \times 10^{-3} \mathrm{~cm}^{2} / \mathrm{sec}$. Histopathological diagnosis revealed no malign cells in the drainage material and the lesion was regarded consistent with a breast abscess.

cysts/abscesses is $0.6 \times 10^{-3} \mathrm{~cm}^{2} / \mathrm{sec}$ with $61.9 \%$ sensitivity, $94.9 \%$ specificity, $61.9 \% \mathrm{PPV}$, and $94.9 \%$ NPV. For these parametres different values have been reported in the literature and they are summarized in Table 4 for comparison ${ }^{(7,8,17,18,21,22,24,25)}$.

The limitations of our study are low number of

Table 4. The cut-off ADC values $\left(\times 10^{-3} \mathrm{~cm}^{2} / \mathrm{sec}\right)$ calculated in our study and similar studies.

\begin{tabular}{lccc}
\hline & $\begin{array}{c}\text { Cut-off } \\
\text { ADC value }\end{array}$ & Sensitivity (\%) & Specificity (\%) \\
\hline Guo et al. $^{(7)}$ & 1.30 & 93 & 88 \\
Rubesova et al. $^{(17)}$ & 1.13 & 86 & 86 \\
Hatakenaka et al. $^{(8)}$ & 1.48 & 83.9 & 81.3 \\
Marini et al. $^{(21)}$ & 1.1 & 80 & 81 \\
Marini et al. $^{(21)}$ & 1.3 & 100 & 67 \\
Woodhams et al. $^{(18)}$ & 1.6 & 93 & 46 \\
Luo et al. $^{(22)}$ & 1.22 & 88.9 & 87.9 \\
Arantes Pereira et al. ${ }^{(24)}$ & 1.24 & 92.3 & 96.2 \\
In our study & 1.1 & 94.5 & 87 \\
& & & \\
\hline
\end{tabular}

cases and the retrospective nature of the study. The important feature of our study is that the lesions detected in post-contrast images manifested in b-0 and b1000 DWI and that a measurement circle (ROI) was placed on the reciprocation of the lesion at b1000 on the ADC map to obtain ADC values. In addition, in literature, the studies about examination of complicated cysts and abscesses of the breast using DWI are limited in number. and malignant, benign lesions, and complicated cyst/abscess groups have not been analyzed in combination using DWI yet.

Finally, when all the findings of our study are reviewed together, it is detected that the specificity, PPV and NPV of DWI are higher than conventional MRI, and no significant difference between DWI, and conventional MRI was detected as for sensitivity when DWI is used alone. Thus, in our study it is 

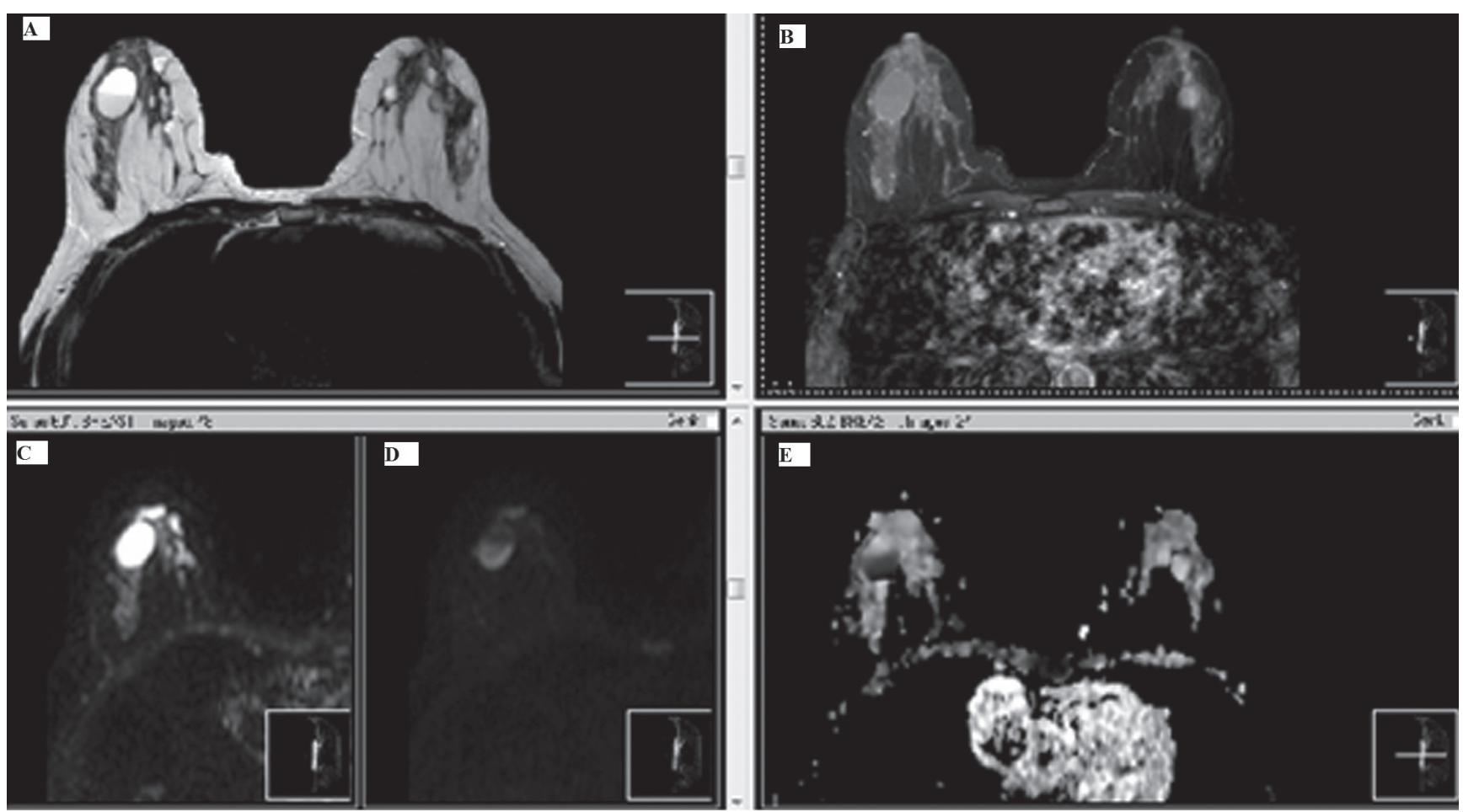

Figure 5.39-year-old female. In the central area of the right breast, a $2.5 \mathrm{~cm}$ T2A hyperintense cystic lesion with fluid-fluid levels that is circumferentially contrasted in post-contrast (B) images is present. The lesion was regarded as a BIRADS 3 complicated cyst. In the lesion's area with fluid leveling diffusion is restricted in DWI (C-b0; D-b1000) and the lesion's ADC (E) level was measured as $0.59 \times 10^{-3} \mathrm{~cm}^{2} / \mathrm{sec}$. No malign cytology was identified in the material obtained from the FNAB.

concluded that DWI is effective in detecting and distinguishing malignant and benign lesions, but we suggest that for best result, DWI must be used together with conventional MRI since current DWI technology yields poor resolution, and also it may be useful in distinguishing complicated cysts/abscesses from malignant lesions.

\section{Conflict of Interest Statement:}

The authors have no conflict of interest.

\section{REFERENCES}

1. Macura KJ, Ouwerker R, Jacobs MA, et al. Patterns of enhancement on breast MR images: interpretation and imaging pitfalls. Radiographics 2006;26:1719-1734.

https://doi.org/10.1148/rg.266065025

2. Kuhl CK, Mielcareck P, Klaschik S, et al. Dynamic breast MR imaging: are signal intensity time course data useful for differential diagnosis of enhancing lesions? Radiology 1999;211:101-110.

https://doi.org/10.1148/radiology.211.1.r99ap38101

3. Fischer U, Kopka L and Grabbe E. Breast carcinoma: effect of preoperative contrast enhanced MR imaging on the therapeutic approach. Radiology 1999;213:881-888. https://doi.org/10.1148/radiology.213.3.r99dc01881

4. Kinoshita T, Yashiro N, Ýhara N, Funatu H, Fukuma E, Narita M. Diffusion - weighed half - Fourier single - shot turbo spin echo imaging in breast tumors: differentiation of invasive ductal carcinoma from fibroadenoma. J Comput Asist Tomogr 2002;26:1042-1046. https://doi.org/10.1097/00004728-200211000-00033

5. Morris EA. Breast cancer imaging with MRI. Radiol Clin North Am 2002;40:443-466. https://doi.org/10.1016/S0033-8389(01)00005-7

6. Namimoto T, Yamashita Y, Sumi S et al. Focal liver masses characterization with diffusion-weighted. Radiology 1997;204:739-744.

https://doi.org/10.1148/radiology.204.3.9280252

7. Guo Y, Cai YQ, Cai ZL, et al. Differentiation of clinically benign and malignant breast lesions using diffusion weighted imaging. J Magn Reson Imaging 2002;16(2):172-178. https://doi.org/10.1002/jmri.10140

8. Hatakenaka M, Soeda H, Yabuuchi $H$, et al. Apparent Diffusion Coefficients of Breast Tumors: Clinical Application. Magn Reson Med Sci 2008; 7:23-29. https://doi.org/10.2463/mrms.7.23

9. Berg WA, Sechtin AG, Marques H, Zhang Z. Breast Masses and the ACRIN 6666 Experience. Radiol Clin North Am 2010;48(5):931-987. https://doi.org/10.1016/j.rcl.2010.06.007

10. Soderstrom CE, Harms SE, Copit DS, et al. Three-dimensional RODEA breast MR imaging of lesions containing ductal carcinoma in situ. Radiology 1996;201:427-432. https://doi.org/10.1148/radiology.201.2.8888235

11. Kuroki Y, Nawano S, Hasebe T, et al. Efficacy of MR mam- 
mography (MRM) in providing preoperative locoregional information on breast cancer: correlation between MRM and histological findings. Magn Reson Med Sci 2002;1:73-80. https://doi.org/10.2463/mrms.1.73

12. Bluemke DA, Gatsonis CA, Chen MH, et al. Magnetic resonance imaging of the breast prior to biopsy. Jama 2004;292:2735-2742. https://doi.org/10.1001/jama.292.22.2735

13. Sinha S, Lucas-Quesada FA, Sinha U, et al. In vivo diffusionweighted MRI of the breast: potential for lesion characterization. J Magn Reson Imaging 2002;15:693-704. https://doi.org/10.1002/jmri.10116

14. Ducatman BS, Emery ST, Wang HH. Correlation of histologic grade of breast carcinoma with cytologic features on fineneedle aspiration of the breast. Mod Pathol 1993;6:539-543.

15. Le Bihan D, Breton E, Lallemand D, et al. MR imaging of intravoxel incoherent motions: application of diffusion and perfusion in neurologic disorders. Radiology 1986;161:401-407. https://doi.org/10.1148/radiology.161.2.3763909

16. Buadu LD, Murakami J, Murayama S, et al. Breast lesions: correlation of contrast medium enhancement patterns on MR images with histopathologic findings and tumor angiogenesis. Radiology 1996;200:639-649. https://doi.org/10.1148/radiology.200.3.8756909

17. Rubesova E, Grell AS, De Maertelaer V, et al. Quantitative diffusion imaging in breast cancer: a clinical prospective study. J Magn Reson Imaging 2006;24:319-324. https://doi.org/10.1002/jmri.20643

18. Woodhams R, Matsunaga K, Iwabuchi K, et al. Diffusionweighted imaging of malignant breast tumors: the usefulness of apparent diffusion coefficient (ADC) value and ADC map for the detection of malignant breast tumors and evaluation of cancer extension. J Comput Assist Tomogr 2005;29:644-649. https://doi.org/10.1097/01.rct.0000171913.74086.1b

19. Kuroki Y, Nasu K, Kuroki S, et al. Diffusion-weighted imaging of breast cancer with the sensitivity encoding technique: analysis of the apparent diffusion coefficient value. Magn Reson Med Sci 2004;3:79-85. https://doi.org/10.2463/mrms.3.79

20. Lucas-Quesada FL, Sinha C, DeBruhl ND, et al. Estimation of diffusion coefficients for benign and malignant breast lesions using echo planar MR imaging. Radiology 1998;209(Suppl):468.

21. Marini C, Iacconi C, Giannelli M, et al. Quantitative diffusion-weighted MR imaging in the differential diagnosis of breast lesion. Eur Radiol 2007; 17:2646-2655. https://doi.org/10.1007/s00330-007-0621-2

22. Luo JD, Liu YY, Zhang XL, et al. Application of diffusionweighted magnetic resonance imaging to differential diagnosis of breast diseases. Ai Zheng 2007;26(2):168-171.

23. SC Partridge, CD Mullins, BF Kurland, et al. Apparent diffusion coefficient values for discriminating benign and malignant breast MRIlesions: effects of lesion type and size. AJR Am J Roentgenol 2010;194:1664-1673. https://doi.org/10.2214/AJR.09.3534

24. Pereira FPA, Martins G, Figueiredo E et al. Assessment of breast lesions with diffusion-weighted MRI: comparing the use of different b values. AJR Am J Roentgenol 2009;193:1030-1035. https://doi.org/10.2214/AJR.09.2522

25. Esen OS, Canverenler S, Adibelli ZH, Mollamehmetoglu H, Atasoy I, Erkan N. Memede klasik ve diffüzyon ağırlıklı manyetik rezonans görüntülemede komplike kist-apselerin özellikleri (Properties of complicated cysts/abcesses in conventıonal and diffusion-weighed breast MRI). Tepecik Ĕgit Hast Derg 2014;24(2):87-92. https://doi.org/10.5222/terh.2014.09719 